\title{
The S-layer gene of Lactobacillus helveticus CNRZ 892 : cloning, sequence and heterologous expression
}

\author{
M. Luisa Callegari, ${ }^{1}$ Barbara Riboli, ${ }^{1}$ J. Willem Sanders, ${ }^{2}$ \\ P. Sandro Cocconcelli, ${ }^{1}$ Jan Kok, ${ }^{2}$ Gerard Venema ${ }^{2}$ and Lorenzo Morelli ${ }^{1}$
}

Author for correspondence: M. Luisa Callegari. Tel: +39523 599248. Fax: +39523599246.

e-mail:mcallega@cr.unicatt.it

\begin{abstract}
1 Istituto di Microbiologia, UCSC, Via Emilia Parmense 84, 29100 Piacenza, Italy

2 Department of Genetics, RUG, Kerklaan 30, 9751NN Haren, The Netherlands
\end{abstract}

\begin{abstract}
Lactobacillus helveticus CNRZ 892 contains a surface layer (S-layer) composed of protein monomers of $43 \mathrm{kDa}$ organized in regular arrays. The gene encoding this protein $(s / p H)$ has been cloned in Escherichia coli and sequenced. s/pH consists of $\mathbf{4 4 0}$ codons and is preceded by a ribosome-binding site (RBS) and followed by a putative $\rho$-independent terminator. Indeed, Northern analysis revealed that $s / p H$ is a monocistronic gene. The gene is preceded by a possible promoter of which the -35 and -10 hexanucleotides are separated by 17 nt. By primer extension analysis the transcription start site was mapped at $7 \mathrm{nt}$ downstream of the -10 sequence while the deduced amino acid sequence of SIpH shows a leader peptide of 30 aa. The s/pH gene has been amplified by PCR and the fragment, carrying the complete gene from the RBS to the stop codon, has been cloned in a lactococcal gene expression vector downstream of promoter P32. Lactococcus lactis MG1363 carrying the resulting plasmid produced and secreted an S-layer monomer with the same molecular mass as the authentic L. helveticus CNRZ 892 SIPH, as judged by SDS-PAGE. Immunoelectron microscopy revealed that SIpH was bound to the lactococcal cell walls in small clumps and accumulated in the growth medium as small sheets.
\end{abstract}

Keywords: S-layer, Lactobacillus helveticus, cloning, heterologous expression

\section{INTRODUCTION}

Surface layers (S-layers) composed of protein monomers arranged in crystalline arrays have been described on Lactobacillus cell walls (Messner \& Sleytr, 1992; Lortal, 1993). Monomeric subunits of Lactobacillus S-layers have been successfully isolated by extraction with urea (Masuda \& Kawata, 1979), guanidine $\mathrm{HCl}$ (Masuda \& Kawata, 1980), SDS (Bhowmik et al., 1985) and LiCl (Callegari et al., 1990; Lortal et al., 1992). The amino acid composition of Lactobacillus S-layers has been determined by chemical methods (Masuda \& Kawata, 1992) and has revealed the presence of a high proportion of hydrophobic amino acids. The molecular mass of Slayer monomers isolated from lactobacilli was found to range from 40 to $60 \mathrm{kDa}$. Hexagonal, square and oblique

\footnotetext{
The EMBL/GenBank accession numbers for the nucleotide sequences reported in this paper are X91199 (ORF of $s / p H$ ) and AJ001931 (promoter region of $s(p H)$.
}

symmetries have been observed in the ultrastructures of S-layers (Messner \& Sleytr, 1992). Upon removal of agents used for their isolation, S-layer monomers extracted from Lactobacillus brevis (Masuda \& Kawata, 1980) and Lactobacillus helveticus (Lortal, 1993) have been shown to be able to spontaneously reassemble into crystalline arrays with the same characteristics as those observed in intact cells.

The functional properties of S-layers of lactobacilli have not yet been elucidated; it appears that freeze-drying can induce the detachment of S-layer monomers from the cell wall of Lactobacillus acidophilus but structural damage is not related to loss of cell viability (Ray \& Johnson, 1986). Resistance to lysozyme treatment has been related to the presence of an S-layer as the outermost envelope of L. helveticus ATCC 12046 (Lortal et al., 1992). A positive relationship has also been suggested between the ability to adhere to chicken epithelia and the presence of an S-layer in an avian isolate of L. acidophilus (Schneitz et al., 1993). We have 
suggested a role for the S-layer of $L$. helveticus CNRZ 892 as receptor for the virulent bacteriophage CNRZ 832-B1 (Callegari et al., 1990).

The deduced amino acid sequences of S-layer monomers of $L$. brevis ATCC 8287 (Vidgren et al., 1992) and $L$. acidophilus ATCC 4356 (Boot et al., 1993) show both proteins to be positively charged (deduced isoelectric points of 9.37 and 9.40 , respectively) with limited $(35.7 \%)$ amino acid sequence similarity. From the latter strain an additional silent gene sharing extensive homology with the active gene of the same strain has been identified, cloned and sequenced (Boot et al., 1995). With antisera raised against the Lactobacillus buchneri ATCC 4005 S-layer protein it was shown that S-layer monomers isolated from lactobacilli belonging to different species are not immunologically related (Masuda $\&$ Kawata, 1983). Nevertheless, the N-terminal amino acid sequence of the L. helveticus ATCC 12046 S-layer protein (Lortal, 1993) and the deduced $\mathrm{N}$-terminal amino acid sequence of the L. acidophilus ATCC 4356 protein turned out to be nearly identical (Boot et al., 1993). These two species belong to the obligatory homofermentative group of Lactobacillus and have been shown to be phylogenetically related by DNA-DNA hybridization data and rRNA sequences analysis (Kandler \& Weiss, 1986).

Here we present the cloning and nucleotide sequence of the gene encoding the $S$-layer protein of $L$. belveticus CNRZ 892 and its expression in the Gram-positive heterologous host Lactococcus lactis.

\section{METHODS}

Bacterial strains and culture conditions. L. helveticus CNRZ 892 (ATCC 10386) and ATCC 12046 were propagated in MRS (Oxoid) broth or agar at $42^{\circ} \mathrm{C}$. Escherichia coli strains TB1 and LE 392 were cultivated at $37^{\circ} \mathrm{C}$ in LB broth (Sambrook et al., 1989). Lactococcus lactis MG1363 was grown at $30^{\circ} \mathrm{C}$ in M17 (Oxoid). Ampicillin was used at $100 \mu \mathrm{g} \mathrm{m}^{-1}$ for E. coli. Erythromycin was used at $5 \mu \mathrm{g} \mathrm{ml}^{-1}$ for Lc. lactis.

Purification of S-layer protein and preparation of specific antibodies. S-layer protein (SlpH) of L. helveticus CNRZ 892 and ATCC 12046 was purified following procedures based on a $6 \mathrm{M} \mathrm{LiCl}$ extraction as described previously (Callegari et al., 1990). The extraction procedure was repeated until SDSPAGE (Laemmli, 1970) revealed a single band of SlpH monomers stainable with Coomassie brilliant blue. Purified $\mathrm{SlpH}$ was used to obtain a rabbit antiserum (kindly provided by Centro Zooprofilattico, Brescia, Italy).

DNA techniques, transformation and nucleotide sequence analysis. General DNA techniques were performed as described by Sambrook et al. (1989). All DNA modification enzymes were purchased from Boehringer Mannheim. Genomic DNA of L. helveticus CNRZ 892 was isolated following the procedure described by Lewington et al. (1987). Chromosomal DNA of $L$. belveticus CNRZ 892 was partially digested with Sau3AI and cloned in $\lambda$ GEM-11 XboI half site arms (Promega). The Packagene in vitro Packaging System (Promega) was used for in vitro packaging of recombinant phages. E. coli and Lc. lactis were electrotransformed as described by Dower et al. (1988) and Holo \& Nes (1989), respectively. Nucleotide sequencing was performed on the Applied Biosystems 373A automated DNA sequencer using the ABI PRISM Dye Terminator Cycle Sequencing and Dye Primer Cycle Sequencing kits (Perkin Elmer).

The Genetic Computer Group sequence analysis package (University of Wisconsin) was used to assemble and analyse the sequences. Nucleotide and predicted amino acid sequences were compared to those in the databases (GenBank, Release 50.0; SWISS-PROT, Release 33.0; Prosite, Release 13.0) using the FASTA (Pearson \& Lipman, 1988) and BLAST (Altschul et al., 1990) programs.

Oligonucleotides and PCR. Oligonucleotides used in this work are listed in Table 1 . They were synthesized with an Applied Biosystems model 391 DNA synthesizer. Primer 1 was based on the $\mathrm{N}$-terminal amino acid sequence of $L$. helveticus ATCC 12046 S-layer protein (Lortal et al., 1992). Inverse PCR with primers 2 and 3 on AsnI-digested and self-ligated chromosomal DNA of L. helveticus CNRZ 892 (20 ng) was done using 25 cycles of $1 \mathrm{~min}$ at $94^{\circ} \mathrm{C}$ for denaturation, $1 \mathrm{~min}$ at $50^{\circ} \mathrm{C}$ for annealing and $2 \mathrm{~min}$ at $72^{\circ} \mathrm{C}$ for extension. Prior to PCR the AsnI fragments of the proper size were recovered from an agarose gel using GeneClean (Bio-101). Primers 6 and 7 were used to amplify a chromosomal DNA fragment containing $\operatorname{slpH}$ devoid of its promoter by using 25 cycles of $1 \mathrm{~min}$ at $94^{\circ} \mathrm{C}, 1 \mathrm{~min}$ at $45^{\circ} \mathrm{C}$ and $2 \mathrm{~min}$ at $72^{\circ} \mathrm{C}$. Taq polymerase (Boehringer Mannheim) was used for all amplification reactions. The fragment resulting from this PCR procedure was digested with $S p h \mathrm{I}$ and SalI (these two

Table 1. Oligonucleotides used as primers in PCR reactions or probes in this study

\begin{tabular}{|llc|}
\hline Primer & \multicolumn{1}{c|}{$\begin{array}{c}\text { Sequence* } \\
\end{array}$} & $\begin{array}{c}\text { Position from } \\
\text { AUG start codon }\end{array}$ \\
\hline 1 & GCA/T ACT/A ACT/A ATT/C AAT/C GCA/T GAT/C AGT/C GCA/T ATT/C AAT/C & 90 to 123 \\
2 & AAC ATT ACA TCT GTG GTA GC & 662 to 681 \\
3 & CTT AAT TTG TAC ACT TGA AAG C & 522 to 544 \\
4 & GGT GCA ACA GCT AAT AAA GCA GCA GCA GCA GC & 27 to 59 \\
5 & GTA ATA GGC CAT AGG TTC AGC ATG AGA & -59 to -32 \\
6 & CAG ATG ATA TCG CAT GCT TAT TCA AAG TTA GCA ACC TTA AC & 1297 to 1320 \\
7 & AAC GCG TCG ACA TGC ATC ATT ATA GGC TCC TTT CTC ATG & -74 to -52 \\
8 & GCC TTG CCG TTT TCG ATT AC & 1070 to 1090 \\
\hline
\end{tabular}

* The sequences in bold are not present in the $s l p H$ gene but they were added in designing primers to introduce useful restriction sites at both ends of the PCR products. 
restriction sites were added to the $5^{\prime}$ end of primers 6 and 7 , respectively) and ligated to the expression vector pMG36e (van de Guchte et al., 1989) cut with Sall and SphI. The resulting construct, pMC01, was recovered after electrotransformation of $L c$. lactis MG1363.

Southern blotting and hybridization. DNA was transferred from agarose gels to a positively charged nylon membrane (Boehringer Mannheim) using the method of Southern (1975). Hybridization and probe detection were done using DIGlabelled oligonucleotides according to the instructions of the manufacturer (Boehringer Mannheim).

RNA methods. Total RNA was isolated from $200 \mathrm{ml}$ of a culture of $L$. helveticus CNRZ 892 grown to exponential phase $\left(\mathrm{OD}_{600} 0 \cdot 5\right)$. Cells were collected, washed with TE buffer ( $\mathrm{pH} 8$ ) and resuspended in $3 \mathrm{ml}$ of the same buffer. The cell suspension was dispensed in six tubes $(0.5 \mathrm{ml}$ per tube). After addition of $170 \mu \mathrm{l} 2 \%$ macaloid, $500 \mu \mathrm{l}$ phenol/ chloroform (24:1), $50 \mu 1$ 10\% SDS and 0.8 g glass beads, cells were disrupted using a Shake-it-baby (Biospec Products). Glass beads were collected by centrifugation at $12000 \mathrm{~g}$ for $15 \mathrm{~min}$. After two extractions with phenol/chloroform $(24: 1)$ RNA was precipitated by addition of 0.1 vols $2 \mathrm{M} \mathrm{NaCl}$ and 2.5 vols ethanol and collected by centrifugation at $17000 \mathrm{~g}$ for $12 \mathrm{~min}$.

The pellet was dissolved in $20 \mathrm{mM}$ EDTA ( $\mathrm{pH} 8$ ) and the RNA was precipitated with 2 vols $4.5 \mathrm{M}$ sodium acetate ( $\mathrm{pH} 7)$. RNA was pelleted by centrifugation $(17000 \mathrm{~g}$ for $10 \mathrm{~min})$, washed twice with ethanol $(70 \%)$ and dissolved in distilled water. RNA gel electrophoresis, Northern blotting, labelling of primers and primer extension were performed as described by Sambrook et al. (1989). The lengths of the primer extension products were determined by comparison with the products of a sequencing reaction using primer 5 and an $E$. coli clone containing the inverse PCR product as template.

SDSPAGE and Western analysis. Cells from $1 \mathrm{ml}$ of an overnight culture of Lc. lactis were collected by centrifugation and resuspended in $100 \mu \mathrm{l}$ water and $20 \mu \mathrm{l}$ solubilizing solution (10\% $\beta$-mercaptoethanol, $10 \%$ glycerol, $4 \%$ SDS, $500 \mathrm{mM}$ Tris/ $\mathrm{HCl}, \mathrm{pH} \mathrm{8,} \mathrm{0.02} \mathrm{M} \mathrm{EDTA,} \mathrm{pH} \mathrm{8,} 10 \%$ bromophenol blue). The sample was boiled for $5 \mathrm{~min}$ and centrifuged. The supernatant was examined by SDS-PAGE according to Laemmli (1970) using a stacking gel containing $3 \%$ acrylamide and a $12 \%$ running gel. The supernatant of the bacterial culture was precipitated with TCA as described by Séchaud $e t$ al. (1989). The pellet obtained was resuspended in distilled water and then analysed by SDS-PAGE.

S-layer proteins extracted by the same procedure from cells and supernatants of strain CNRZ 892 and ATCC 12046 were used as positive controls. After electrophoresis proteins on the gels were electroblotted onto nitrocellulose membrane (BioRad). Anti-SlpH serum was diluted 1:10000. Goat anti-rabbit IgG conjugated to horseradish peroxidase (Sigma) was used as a secondary antibody to detect the S-layer protein antigen.

Immunogold labelling and electron microscopy. Cells from $1 \mathrm{ml}$ of a culture of Lc. lactis were collected by centrifugation and resuspended in $300 \mu$ l blocking solution (1\% BSA in PBS) containing $10 \mu \mathrm{l}$ of a 1:1000 dilution of anti-SlpH serum. After two washings in PBS, $500 \mu$ l of a 1:100 dilution of a $5 \mathrm{~nm}$ goldlabelled anti-rabbit IgG (Sigma) in blocking solution were added. After $10 \mathrm{~min}$ of incubation, cells were washed in PBS, prefixed with $2.5 \%$ glutaraldehyde and fixed with $1 \% \mathrm{OsO}_{4}$ (Lortal et al., 1991). The samples were embedded in Epon resin (Fluka) and thin sections $(50 \mathrm{~nm})$ were prepared using a Reichert-Jung Ultracut microtome (Optische Werke). The sections were stained with $4 \%$ uranyl acetate and then with $0.4 \%$ lead citrate and examined with a JEOL JEE 1200 EXII electron microscope at $80 \mathrm{kV}$.

\section{RESULTS}

\section{Purification of the Stayer protein of $L$. helveticus CNRZ 892}

$\mathrm{LiCl}$ extraction is a generally employed method to isolate S-layer proteins from L. helveticus (Callegari et al., 1990; Lortal et al., 1992). Sequential extraction with a concentrated $(6 \mathrm{M}) \mathrm{LiCl}$ solution was used to purify a single protein from L. helveticus CNRZ 892 as shown by SDS-PAGE and staining with Coomassie brilliant blue (Fig. 1a) as well as with silver staining (data not shown). The molecular mass of this protein, SlpH, was estimated by SDS-PAGE to be close to $43 \mathrm{kDa}$. Rabbit antiserum raised against the protein cross-reacted with the S-layer protein of L. helveticus ATCC 12046, suggesting that there is some homology between the two proteins (Fig. 1b).

\section{Cloning of slpH gene of L. helveticus CNRZ 892}

Oligonucleotide 1 (Table 1 ), based on the $\mathrm{N}$-terminal amino acid sequence of the S-layer protein of $L$. belveticus ATCC 12046 (Lortal et al., 1992), hybridized with a Sau3AI partial digest of chromosomal DNA of $L$. belveticus CNRZ 892. A genomic library of L. belveticus CNRZ 892 in $\lambda \mathrm{GEM}-11\left(4 \times 10^{4}\right.$ recombinant phages)

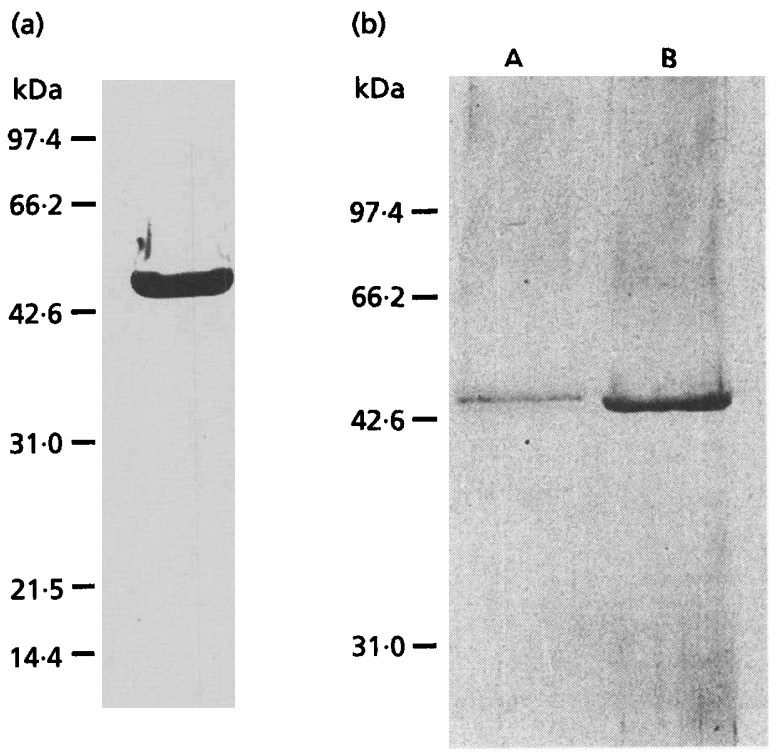

Fig. 1. (a) PAGE (14\% acrylamide) of S-layer monomers purified from L. helveticus CNRZ 892. The gel is stained with Coomassie brilliant blue. (b) Western immunoblot analysis of S-layer proteins extracted from strains $L$. helveticus CNRZ 892 (lane A) and ATCC 12046 (lane B) using serum raised against SlpH. BioRad low molecular mass markers were used as reference. 

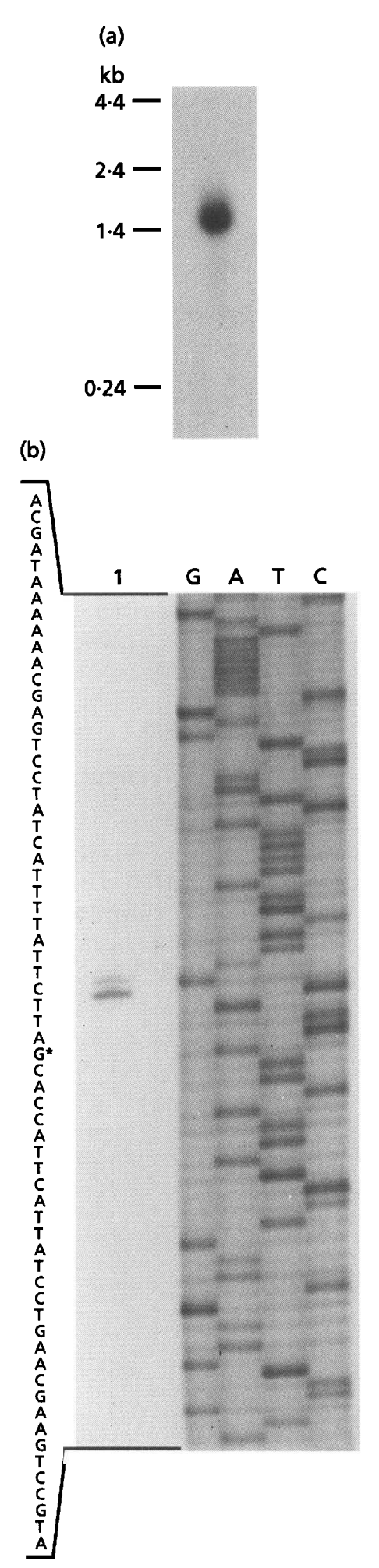

Fig. 2. (a) Northern hybridization analysis. Total $L$. helveticus CNRZ 892 RNA $(20 \mu \mathrm{g})$ was run on a $1 \%$ agarose gel, blotted onto a positively charged nylon membrane and hybridized with 32P-labelled primer 5 (Table 1) as probe. RNA molecular mass markers were used to determine transcript size. (b) Results of a primer extension experiment done with $15 \mu \mathrm{g}$ total RNA isolated from $L$. helveticus CNRZ 892 using primer 5 (Table 1) as a start point for the extension. Lanes: 1, extended product; GATC, partial sequence of the putative promoter region using the same primer. The asterisk shows the start point of s/pH. was screened using the rabbit antiserum raised against $\mathrm{SlpH}$. Four positive phages were identified and all four shared a $6.3 \mathrm{~kb}$ Sall fragment (data not shown). A DNA fragment of this size also reacted in Southern hybridizations of chromosomal DNA cut with Sall using oligonucleotide 1 as probe (data not shown). The common Sall fragment gave four fragments $(3 \cdot 7,1 \cdot 6,0 \cdot 5$ and $0.4 \mathrm{~kb}$ ) when digested with HindIII. These fragments were ligated to pUC18 cut with HindIII alone or in combination with SalI. Two different HindIII clones carried fragments of 526 and $435 \mathrm{bp}$ which were sequenced completely. The nucleotide sequences of these two fragments showed a high degree of homology to the $3^{\prime}$ end of the L. acidophilus ATCC 4356 slpA gene (Boot et al., 1993) with the 435 bp fragment containing the $3^{\prime}$ end of $s l p H$ and the other fragment carrying sequences immediately upstream thereof (see below). All attempts to clone the $1.6 \mathrm{~kb}$ fragment, positive with oligonucleotide 1 in Southern hybridization, failed. Also, the production of SlpH by the recombinant phages was soon lost, indicating poor stability of the $s l p H$ gene in this vector. All attempts to clone the $5^{\prime}$ end directly from chromosomal DNA fragments of $L$. belveticus CNRZ 892 failed. A detailed restriction enzyme map was made of the chromosomal region around $s l p H$ and by deduction it was concluded that an AsnI fragment would contain the start of $s l p H$ with its promoter. Two primers ( 2 and 3 in Table 1 ) were designed to amplify this fragment by inverse PCR. The PCR products of three independent amplification reactions were cloned in pGEM-T in E. coli and used to complete the nucleotide sequence of $s l p H$. All PCR-amplified fragments were checked by nucleotide sequence analysis and no mistakes and/or rearrangements were detected. To verify that there is no sequence gap between the two HindIII fragments, a PCR amplification product, obtained with primers 3 and 8 , was directly sequenced using the same primers. The sequence analysis confirmed that the two fragments were contiguous and shared a HindIII site.

\section{slpH sequence analysis}

The ORF of $s l p H$ contains $1320 \mathrm{nt}$ and is preceded by a putative ribosome-binding site (AGGAGG) located $9 \mathrm{nt}$ upstream of the AUG start codon. It is followed by a single stop codon (UAA) and a possible $\rho$-independent transcription terminator. slpH contains 12 direct repeated sequences ranging from 7 to $16 \mathrm{nt}$. Computer analysis suggested the presence of putative -10 (TAAAAT) and -35 (TTGCTA) boxes upstream of the AUG start codon. The functionality of this putative promoter was confirmed by primer extension analysis (see below).

The deduced amino acid sequence from residues 31 to 42 of SlpH of L. helveticus CNRZ 892 (ATTINADSAINA) is identical to the $\mathrm{N}$-terminal amino acid sequence determined from the purified S-layer protein monomer of L. helveticus ATCC 12046 (Lortal et al., 1992). This indicates that $L$. helveticus SlpH has a signal peptide of 30 aa. This 30 aa $\mathrm{N}$ terminus complies with the rules of 


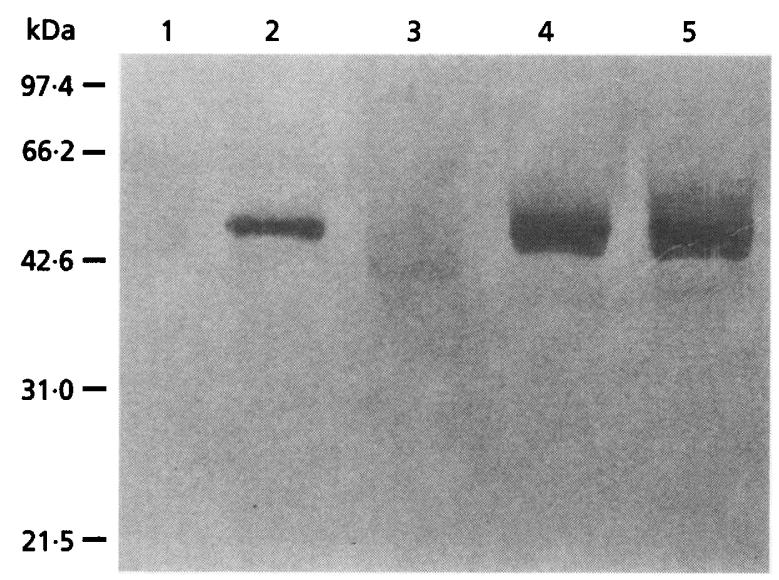

Fig. 3. Immunoblotting analysis of LC. lactis MCO1 proteins extracted from $3 \mathrm{ml}$ of supernatant (lane 2) and from $1 \mathrm{ml}$ of cells taken from an overnight culture (lane 4). As negative control, proteins recovered by TCA treatment from $3 \mathrm{ml}$ of supernatant of Lc. lactis MG1363 were loaded in lane 1, while lane 3 contains protein extracted from $1 \mathrm{ml}$ of cells of the same strain. In lane 5 proteins extracted from the positive control, $L$. helveticus CNRZ 892, are visible. Bio-Rad low molecular mass markers were used as reference.

von Heijne (1986) for genuine prokaryotic signal sequences. The predicted cleavage site is located between alanine residues 30 and 31 . The deduced molecular mass of mature SlpH is $43.1 \mathrm{kDa}$, which is in accordance with the molecular mass of $43 \mathrm{kDa}$ as determined by SDSPAGE. The deduced isoelectric point is $10 \cdot 19$.

\section{Analysis of mRNA of slpH}

Primer 5 is located $31 \mathrm{bp}$ upstream of the AUG start codon of slpH and was used as probe in Northern hybridization. A $1.5 \mathrm{~kb}$ transcript was detected, indicating that $\operatorname{slpH}$ is a monocistronic gene (Fig. 2a). Primer extension using primer 5 revealed a major transcription start point (Fig. 2b) located at a $G$ residue $190 \mathrm{nt}$ upstream of the AUG start codon. The coding region is preceded, at $198 \mathrm{nt}$ from the AUG start codon and at $7 \mathrm{nt}$ from the transcription start point, by a possible -10 sequence (TAAAAT). A -35 sequence (TTGCTA) is located $17 \mathrm{nt}$ upstream of the -10 sequence. A similar promoter structure has been found upstream of $s l p A$ of L. acidophilus ATCC 4356 (Boot et al., 1993).

\section{Cloning and expression of the S-ayer protein in Lc. lactis MG1363}

As the entire $s l p H$ gene was unstable in $E$. coli, we decided to clone the gene behind another promoter in Lc. lactis. To do this a fragment carrying the complete gene from putative RBS up to the stop codon was amplified by PCR using primers 7 and 6 (from position -74 to -52 and from 1297 to 1320 , respectively). The resulting $1390 \mathrm{bp}$ fragment was digested with SalI and $S p h I$ and ligated into the lactococcal expression vector
pMG36e (van de Guchte et al., 1989) cut with the same enzymes. Thus, $\operatorname{slpH}$ was placed under control of the strong lactococcal promoter P32 present in the vector. The ligation mixture was used to electrotransform Lc. lactis MG1363. Transformants were selected for erythromycin resistance and on the basis of a positive reaction in Western blotting with anti-SlpH antiserum. One transformant, carrying the expected pMC01, produced SlpH with a molecular size by SDS-PAGE similar to that of SlpH isolated from L. belveticus CNRZ 892 and was selected for further characterization (Fig. 3). The S-layer protein could be precipitated from the culture supernatant of Lc. lactis (pMC01) with TCA and was present in boiled samples of these cells. Electron microscopy revealed that the protein is shed from the surface of the cells and accumulates in the growth medium (Fig. 4a). Immunogold labelling indicated the presence of few sites on the lactococcal cell walls where small clumps of SlpH are visible (Fig. 4b). A large proportion of the lactococcal cells are bound to each other by what seem to be bridges of SlpH protein.

\section{DISCUSSION}

Our results indicate that the amino acid sequence of $\mathrm{SlpH}$ is highly similar to that determined for the S-layer protein SlpA of L. acidophilus ATCC 4356 (Boot et al., 1993). Similarity to L. acidophilus SlpA is particularly evident in the C-terminal region (from aa 193 to 438) while the middle region shows a lower degree of similarity with the corresponding region of SlpA.

Our failure to clone the entire gene of SlpH in E. coli resembles the problems observed in cloning of other Slayer protein genes (Boot et al., 1993, 1995; Vidgren et al., 1992; Yamagata et al., 1987). Instability of $L$. acidophilus $\operatorname{slpA}$ was postulated to be related to the presence of several direct repeats (Boot et al., 1995). Similar observations have already been described in Bacillus stearothermophilus and Aeromonas salmonicida (Kuen et al., 1994; Chu et al., 1991). In contrast we faced no problem in cloning in $E$. coli the promoter and the $5^{\prime}$ end of $s l p H$ and the entire coding region from the RBS to the stop codon.

The $s l p H$ gene was stably maintained in the Grampositive host Lc. lactis MG1363. The recombinant clone (MC01) carrying slpH under control of P32 had a reduced growth rate in M17 compared to the wild-type strain. Moreover, small 'sand-like' particles were formed by aggregation of cells at the end of the exponential growth phase, that precipitated and left the supernatant completely clear. MC01 produced a protein of the expected size as observed by immunological detection using SlpH antiserum. Lc. lactis MG1363 did not give a signal in immunoblotting even when the amount of examined protein was very high. Immunoelectron microscopy revealed that gold-labelled, SlpHspecific antiserum recognized regularly ordered protein aggregates that were not bound to the lactococcal cell surfaces. Proteins reacting with the $\mathrm{SlpH}$ antiserum were not present on the Lc. lactis MC01 surface except for 

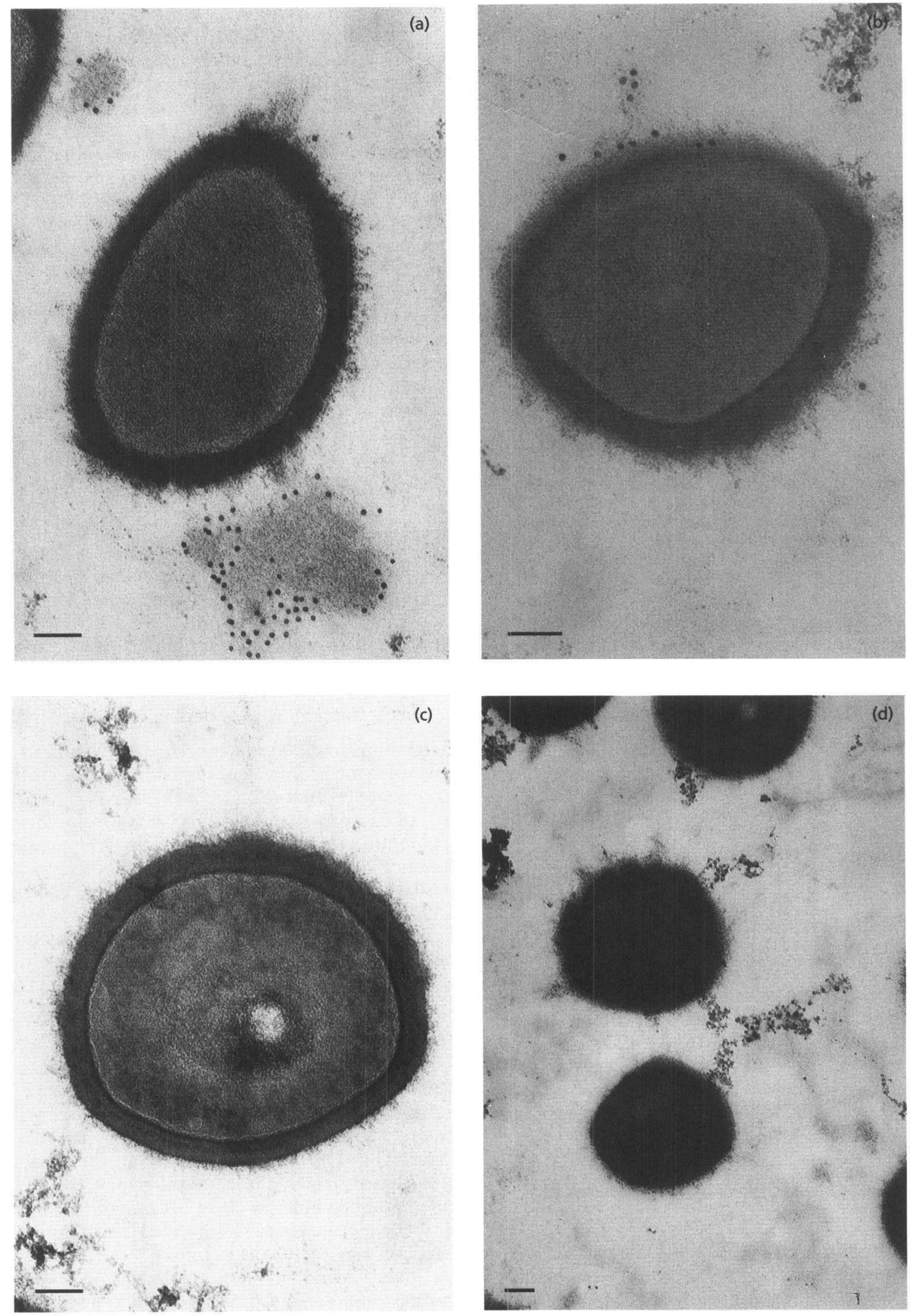

Fig. 4. (a), (b) and (d) Transmission electron microscopy observations of LC. lactis MCO1 thin sections. Cells were treated with anti-SIpH serum and then with $5 \mathrm{~nm}$ gold-labelled anti-rabbit IgG. Thin sections were stained with $4 \%$ uranyl acetate and with $0.4 \%$ lead citrate. (c) Lc. lactis MG 1363 cells were used as control. Bars, $100 \mathrm{~nm}$. 
clumps localized in small spots on each cell (Fig. 4b). The real significance of these aggregation sites has to be investigated further. Moreover, cells were attached to each other by protrusions containing SlpH antigens (Fig. $4 d)$. This observation could explain the sand-like aggregations observed during growth of $L c$. lactis MC01 in broth medium.

A different composition of lactococcal cell walls could explain the observed inability of the cloned S-layer protein to form crystalline arrays on the surface of the new bacterial host: cloning and expression studies of the same construction in a range of lactic acid bacteria, including more closely related lactobacilli, are planned to study reattachment of the protein to heterologous hosts.

The results presented here allow us to investigate more deeply the role played by SlpH in the binding process of the lytic phage CNRZ 832-B1 (Callegari et al., 1990). Spontaneously arising phage-resistant mutants, unable to bind phage particles, are already available (Callegari et al., 1990) and the nucleotide sequences of their slpH genes will be checked to identify mutations possibly involved in the blocking of phage absorption.

\section{ACKNOWLEDGEMENTS}

This work was supported by grants from the European Union BIOTECH (contracts BIO2-CT94-3055 and BIO4-CT96-0402 STARLAB).

\section{REFERENCES}

Altschul, S. F., Gish, W., Miller, W., Myers, E. W. \& Lipman, D. J. (1990). Basic local alignment search tool. J Mol Biol 215, 403-410.

Bhowmik, T., Johnson, M. C. \& Ray, B. (1985). Isolation and partial characterization of the surface protein of Lactobacillus acidophilus strains. Int J Food Microbiol 2, 311-321.

Boot, H. J., Kolen, C. P. A. M., van Noort, J. M. \& Pouwels, P. H. (1993). S-layer protein of Lactobacillus acidophilus ATCC 4356: purification, expression in Escherichia coli and nucleotide sequence of the corresponding gene. J Bacteriol 175, 6089-6096.

Boot, H. J., Kolen, C. P. A. M. \& Pouwels, P. H. (1995). Identification, cloning, and nucleotide sequence of a silent $S$-layer protein gene of Lactobacillus acidopbilus ATCC 4356 which has extensive similarity with the S-layer protein gene of this species. J Bacteriol 177, 7222-7230.

Callegari, M. L., Sechaud, L., Rousseau, M., Bottazzi, V. \& Accolas, J. P. (1990). Le recepteur du phage 832-B1 de Lactobacillus belveticus CNRZ 892 est une proteine. In The 23th Dairy Congress, Montreal, Vol. 1.

Chu, S., Cavaignac, S., Feutrier, J., Phipps, B. M., Kostrzynska, M., Kay, W. W. \& Trust, T. J. (1991). Structure of the tetragonal surface virulence array protein and gene of Aeromonas salmonicida. J Biol Chem 266, 15258-15265.

Dower, W. J., Miller, J. F. \& Radsdale, W. (1988). High efficiency transformation of $E$. coli by high voltage electroporation. Nucleic Acids Res 16, 6127-6145. van de Guchte, M., van de Vossen, J. M. B. M., Kok, J. \& Venema, G. (1989). Construction of a lactococcal expression vector: expression of hen egg white lysozyme in Lactococcus lactis subsp. lactis. Appl Environ Microbiol 55, 224-228.

von Heijne, G. (1986). A new method for predicting signal sequence cleavage sites. Nucleic Acids Res 14, 4683-4690.

Holo, H. \& Nes, I. F. (1989). High efficiency transformation, by electroporation, of Lactococcus lactis subsp. cremoris grown with glycine in osmotically stabilized media. Appl Environ Microbiol 55, 3119-3123.

Kandler, O. \& Weiss, N. (1986). Genus Lactobacillus Beijerinck $1901,212^{\mathrm{AL}}$. In Bergey's Manual of Systematic Bacteriology, Vol. 2, pp. 1209-1219. Edited by P. H. A. Sneath, N. S. Mair, M. E. Sharpe \& J. G. Holt. Baltimore: Williams \& Wilkins.

Kuen, B., Sleytr, U. B. \& Lubitz, W. (1994). Sequence analysis of the $s b s A$ gene encoding the $130-\mathrm{kDa}$ surface layer protein of Bacillus stearothermophilus strain PV72. Gene 145, 115-120.

Laemmli, U. K. (1970). Cleavage of structural proteins during the assembly of the head of bacteriophage T4. Nature 227, 680-685.

Lewington, J., Greenaway, S. D. \& Spillane, B. J. (1987). Rapid small scale preparation of bacterial genomic DNA suitable for cloning and hybridization analysis. Lett Appl Microbiol 5, 51-53.

Lortal, S. (1993). Crystalline surface-layers of the genus Lactobacillus. In Advances in Bacterial Paracrystalline Surface Layers, pp. 57-65. Edited by T. J. Beveridge \& S. F. Koval. New York: Plenum Press.

Lortal, S., Rousseau, M., Boyaval, P. \& van Heijenoort, J. (1991). Cell wall and autolytic system of Lactobacillus helveticus ATCC 12046. J Gen Microbiol 137, 549-559.

Lortal, S., van Heijenoort, J., Gruber, K. \& Sleytr, U. B. (1992). Slayer of Lactobacillus helveticus ATCC 12046 : isolation, chemical characterization and reformation after extraction with lithium chloride. J Gen Microbiol 138, 611-618.

Masuda, K. \& Kawata, T. (1979). Ultrastructure and partial characterization of a regular array in the cell wall of Lactobacillus brevis. Microbiol Immunol 23, 941-953.

Masuda, K. \& Kawata, T. (1980). Reassembly of the regularly arranged subunits in the cell wall of Lactobacillus brevis and their reattachment to cell wall. Microbiol Immunol 24, 299-308.

Masuda, K. \& Kawata, T. (1983). Distribution and chemical characterization of regular arrays in the cell walls of strains of the genus Lactobacillus. FEMS Microbiol Lett 20, 145-150.

Masuda, K. \& Kawata, T. (1992). Heterogeneity of S-layer proteins of Lactobacillus acidophilus strains. Microbiol Immunol 36, 297-301.

Messner, P. \& Sleytr, U. B. (1992). Crystalline bacterial cell surface layers (S-layers). Adv Microbial Physiol 33, 213-275.

Pearson, W. \& Lipman, D. (1988). Improved tools for biological sequence comparison. Proc Natl Acad Sci USA 85, 2444-2448.

Ray, B. \& Johnson, M. C. (1986). Freeze-drying injury of surface layer protein and its protection in Lactobacillus acidophilus. Cryo Lett 7, 210-217.

Sambrook, J., Fritsch, E. F. \& Maniatis, T. (1989). Molecular Cloning: a Laboratory Manual, 2nd edn. Cold Spring Harbor, NY: Cold Spring Harbor Laboratory.

Schneitz, C., Nuotio, L. \& Lounatma, K. (1993). Adhesion of Lactobacillus acidophilus to avian intestinal epithelial cells mediated by the crystalline bacterial cell surface layer (S-layer). $J$ Appl Bacteriol 74, 290-294. 
Séchaud, L., Callegari, M. L., Rousseau, M., Muller, M. C. \& Accolas, J. P. (1989). Relationship between temperate bacteriophage 0241 and virulent bacteriophage 832-B1 of Lactobacillus helveticus. Neth Milk Dairy J 43, 261-277.

Southern, E. M. (1975). Detection of specific sequences among DNA fragments separated by gel electrophoresis. J Mol Biol 98, 503-517.

Vidgren, G., Palva, I., Pakkanen, R., Lounatmaa, K. \& Palva, A. (1992). S-layer protein gene of Lactobacillus brevis: cloning by polymerase chain reaction and determination of the nucleotide sequence. J Bacteriol 174, 7419-7427.

Yamagata, H., Adachi, T., Tsubio, A., Takao, M., Sasaki, T., Tsukagoshi, N. \& Udaka, S. (1987). Cloning and characterization of the $5^{\prime}$ region of the cell wall protein gene operon in Bacillus brevis 47. J Bacteriol 169, 1239-1245.

Received 28 July 1997; revised 13 October 1997; accepted 20 October 1997. 